\title{
Squamous Metaplasia Without Atypia
}

National Cancer Institute

\section{Source}

National Cancer Institute. Squamous Metaplasia Without Atypia. NCI Thesaurus. Code C97137.

A morphologic finding indicating the transformation of glandular or transitional epithelial cells to squamous epithelial cells that lack atypical features. 